\title{
Globalization 4.0 and New Modes of International Cooperation
}

\author{
K. Postel-Vinay
}

Karoline Postel-Vinay - Research Professor, Center for International Research, Sciences Po; 27 rue Saint Guillaume, Paris, France; E-mail: karoline.postelvinay@sciencespo.fr

\begin{abstract}
Since the late 19th century, the international scene has witnessed several waves of globalization that have transformed regulation and cooperation between nations. The current wave - that economists have defined as "globalization 4.0" - is shaped by an industrial revolution that combines digital, physical and biological transformations. Digital technology has a deep structural impact on public and private goods such as health, education, transportation or energy, which changes the terms of the global condition. It disrupts both the organization of societies and the relation between individuals and globalization. Compared to previous waves of globalization, globalization 4.0 affects the international system and runs throughout the global social fabric by increasing throughout the world the level of inequalities and by triggering subsequent polarization and fragmentation. In this global context, our current modes of cooperation and regulation are facing growing issues of legitimacy and efficiency, that are not entirely new, but that are now becoming particularly acute. Those issues of legitimacy and efficiency are furthermore complicated by a shared experience of disconnection from globalization - the rise of the globalization's so-called "left-behinds" - that could be characterized as a form of anomy at the international level. This complex challenge has not yet been fully embraced by the major institutions of global governance. There have been however responses at the sub-global level: connectivity politics, launched by China and followed by the European Union, is one illustration of the new paths that might be taken by global policy makers.
\end{abstract}

Key words: globalization waves; Globalization 4.0; Inequalities; Connectivity politics

For citation: Postel-Vinay K. (2020) Globalization 4.0 and New Modes of International Cooperation. International Organisations Research Journal, vol. 15, no 2, pp. 60-67 (in English). DOI: 10.17323/1996-78452020-02-04

\section{Introduction}

The 2019 World Economic Forum (WEF) in Davos witnessed the emergence of the notion of "globalization 4.0" which is now slowly spreading into academic debates, albeit predominantly in the field of digital studies. It could however also prove useful to illuminate recent trends in global governance and international cooperation, and to address some of the most pressing puzzles that both International Relations (IR) scholars and policy thinkers are confronted with. According to the WEF's white paper published a few months after the 2019 Davos summit, assessing "globalization 4.0" is a mean to understand "how profoundly the context for governance and cooperation is changing due to the Fourth Industrial Revolution" [WEF, 2019, p. 5]. This "Fourth Industrial Revolution" - an expression that was likewise generated by the WEF's conceptual output [Schwab, 2016] - derives from the convergence of digital, physical and biological transformations, whereas the Third Industrial Revolution was essentially the widening access to digital technology. Its dynamics constitute a revolution in a deeper sense with a more 
disruptive impact on the organization of societies and on the relation between individuals and globalization. This disruption defines "globalization 4.0": it is also what economist Richard Baldwin calls "the globotics upheaval" [Baldwin, 2019], i.e. the profound impact of digital technology on public and private goods such as health, education, transportation or energy, that changes the terms of the global condition. This transformation is further complicated by, and partly responsible for, environmental crises and geopolitical shifts. Despite calls for "deglobalization" [Bello, 2002] and nativist entrenchment trends, globalization is not disappearing but, rather, radically evolving. The new globalization entails novel modes of governance and cooperation, and therefore challenges the existing order of international relations.

As its name indicates "globalization 4.0 " is not the first global wave that has redefined relations between states and societies at a world level. International economists such as Richard Baldwin and Philippe Martin [Baldwin, Martin, 1999] have provided a framework of analysis that makes sense of the major global waves witnessed by human communities in a historical perspective. Although the exact starting and ending points of those different waves are hard to define, there is a general understanding of their chronological development. The first wave of globalization started in the late 19th century and was triggered by the transportation and communication revolution - the advancement of steam and coal transport engineering, the invention of long-distance communication tools - that led segments of societies around the world to experience both the perception and the reality of time-space compression on an unprecedented scale. It called for novel means of regulation that materialized into pioneer governance institutions such as the International Telegraph Union, the International Association of Railway Congress or the International Sanitary Convention, the ancestor of the World Health Organization. That first wave ended around 1914, with the breakout of the Great War and the decrease of transnational flows of goods and people. Globalization 2.0 started around the end of the Second World War when the major international organizations that still regulate relations at a planet-level today were conceived and eventually established, i.e. the Bretton Woods system and beyond. Technical innovation was also a factor in the shaping of the new regulation architecture, as illustrated by the creation of the International Atomic Energy Agency. The liberal push of the 1980s and the general lowering of barriers that accompanied the end of the U.S./ USSR confrontation, soon amplified by the emergence of the "world wide web," brought about globalization 3.0. It revived the legitimacy and power of global institutions such as the United Nations and its agencies, but it also activated other cooperation arrangements and in particular regional groupings such as the Asia Pacific Economic Cooperation (APEC) or the Mercosur, as well as global clubs such as the G20. Each wave of globalization since the late 19th century has been a mixture of technological transformations and geopolitical shifts, and each have called for global institutional change. In that sense globalization 4.0 is not essentially different from previous waves, but it does generate unique challenges. Confronted with rising level of inequalities and subsequent polarization and fragmentation, our current modes of cooperation and regulation face growing issues of legitimacy, efficiency and anomy.

\section{The Challenges}

The challenges that are part and parcel of globalization 4.0 need to be analyzed both in the present context of global change, as well as in a historical perspective. The WEF makes a call for a new global architecture that is set against the background of the ongoing transformation of the international scene and the arguments for its case are made accordingly. Yet those arguments, such as the need for more inclusiveness and effectiveness, point to questions that have been regularly raised almost ever since the international institutions inherited from the post-1945 period were established. What makes those questions and related challenges particularly topical 
in the context of globalization 4.0 is the specific blend of geopolitical transformation and technological revolution that characterizes the present wave.

\section{Legitimacy}

There is little doubt that more than a few major international organizations are, in one way or another, in crisis: among others, NATO, according to French president Emmanuel Macron, is experiencing "brain death," whereas the WTO, for a number of analysts, actually "died" [Adlen, 2018]. Globalization 4.0 is, at this early stage and for the time being, a development that is characterized by fragmentation and disruption rather than restructuring and re-ordering. The disruptive capacity of U.S. president Donald Trump has impacted cooperation arrangements and institutions to the point of calling into question their rationale - as, for most of them, the commitment of the world's biggest power has been pivotal - and therefore their very existence.

Doubts about the raison d'être or, when expressed in more political terms, about the legitimacy of the global architecture, are not new. But the concerns have been expressed, until now, in terms of representativeness. Explaining the need for a BRIC summit, when it was launched at Yekaterinburg in 2009, Russian president Dimitri Medvedev remarked: "none of us took part in establishing the international financial system back in the 1930s-40s. I mean, none of our countries took part. Everything was decided for us. We cannot accept this situation again. We need to ensure that our countries, which between them are home to billions of people, take part in setting the new rules of the game" [President of the Russian Federation, 2009]. The demand for more inclusive, and indeed legitimate, modes of cooperation was also at the root of the rise of the South on the international scene in the decades after the Second World War, following the decolonization movement. The largest group representing developing countries, the G77, was established in 1964, in the wake of the first United Nations Conference on Trade and Development (UNCTAD).

Despite the diversity of situations now and then, there has been a recurrent dissatisfaction with the membership of the core entities of the international cooperation system. But the existence of the system itself, sustained by a notion of international community, has not been questioned. The fact that the key architect of the post-1945 cooperation system, the United States, challenges its relevance opens up a complex debate. For a number of global stakeholders it is an invitation to question the legitimacy of the liberal international order whose dominance was more or less taken for granted after 1989.

\section{Efficiency}

Legitimacy and efficiency are strongly interlinked in the perception of international organizations, and this interlinkage plays out more than ever in the dynamics of globalization 4.0. The relative lack of legitimacy that, supposedly, affects informal governance entities such as the G20, has generally been counterbalanced by the efficiency, real or perceived, of the said entities. Conversely, the tolerance for the limits of the efficiency of an institution such as the United Nations has derived from the common perception that its essential legitimacy was hardly debatable, at least until the recent push against multilateralism. The legitimacy/efficiency nexus constitutes a sort of established paradigm well captured by the UN General Assembly (UNGA) president in 2011: "Traditional multilateral institutions, like the UN and the Bretton Woods institutions, are increasingly criticized for not being efficient and representative enough. As a response, new actors, like the G20 and other ad hoc informal groups have emerged. (...) There is a risk for the UN to be marginalized. Suffice it to recall here that when Heads of State and 
government of the G20 met in Pittsburgh, on 24-25 September 2009, to work out a collective response to the economic and financial crisis, the General Debate was still going on at the United Nations in New York!" [ECLAC, 2011].

This paradigm and more specifically the tension between the "legitimacy" argument and the "efficiency" one, have been resolved over time by the regular assessment of groupings such as the G20's output - the pioneer work of the G20 Research Group has been crucial to that effect [Kirton, 2013] - and on the other hand the yearly acknowledgment of the irreplaceable function of an international covenant such as the one provided by the UNGA. Although president Donald Trump has been attending the General Assembly meetings, as well as the G7 and G20 summits, and using them for presenting his worldviews and international policies, he has also expressed the strongest scepticism towards global cooperation since the early 20th century American isolationism. The paradox of a liberal international order whose champion is retreating then brings up the question of the capacity of an engine whose motor is running out of steam. One should note however that the shift in the U.S. attitude towards cooperation reflects a far much larger trend of national retrenchments or, at best, regional realignments. They have made the promotion of any global agenda - from nuclear deterrence to combatting climate change - more challenging.

\section{Anomy}

The disruptive dimension of globalization 4.0 affects the international system and runs throughout the global social fabric. The year 2019 has witnessed numerous movements of social unrest around the world that, even though they occurred in different contexts, share similar expressions of doubt toward the ability of established institutions to deliver material and moral progress. Sociologist Emile Durkheim defined "anomie" as the condition of a society whose internal contract is disintegrating due to the weakening of common norms and values [Durkheim, 1893]. Translated into IR terms, anomy today is the disconnection from globalization, expressed in multiple ways. It is also what commentators have called the rise of the globalization's "left-behinds," which was spectacularly illustrated by the decision of the British people to leave the European Union and the social polarization that this decision revealed. Beyond and before the Brexit moment, however, signs of disconnection were visible in many societies. The WEF's white paper mentioned above argues for the need of a new social contract by noting that while the digital revolution has decisively contributed to the rise of living standards and to the reduction of poverty, there has been "systematic underappreciation of the human impact of rapid economic change, whether due to technology or policy liberalization, in the priorities of national economic policy and the corresponding international institutional architecture" [WEF, 2019, p. 26].

The challenge of anomy is a new element in the recurring debates about the relevance of the international architecture inherited from the post-1945 order. On the positive side, this novelty reflects the emergence of a form of people's empowerment on a new scale, a global "voice" as economist Albert Hirschman would put it [Hirschman, 1970]. But following Hirschman's paradigm of "exit, voice and loyalty" there is a risk of large scale "exit" as well, in the shape of growing resentment and distrust of governments and intermediary bodies.

\section{Responses}

Even before the appearance of the term globalization 4.0, there were signs of a general realization that with the fourth industrial revolution came unforeseen challenges requiring new modes 
of cooperation. For example, the transition, in 2015, from the UN's Millennium Development Goals (MDGs) to the Sustainable Development Goals (SDGs) pointed to the fact that the previous third industrial revolution had markedly boosted economic development, to the point of blurring the clear-cut North/South division - with a majority of the poorest people living in middle-income countries - calling for new approaches to the question of redistribution of global wealth. The growing presence, and visibility, of the globalization's "left-behinds" in both developing and developed societies uncovers issues that are complex and as such have not yet been embraced by the major institutions of global governance. There have been however responses at the sub-global level: the most articulated and far-reaching one has been so far that of China with its "One Belt One Road" (OBOR), later re-branded "Belt and Road Initiative" (BRI). Turning globalization 4.0 on its head, Chinese policy thinkers have presented the new global wave as an opportunity and a turning point in the evolution of world order and modes of cooperation. The Chinese approach to solving the unbalances of globalization, and more specifically its connectivity politics, has triggered other, similar responses, from Asia and Europe. Meanwhile, and as demonstrated during the 2019 summits of the G7 and the G20, there is a now a clearer recognition of the need for re-centring people and people's inclusiveness within the global agenda designing process.

\section{Connectivity}

Looking at globalization 4.0 as a process through which global governance practices are redefined is opening new and potentially fruitful debates within the public policy epistemic community. It has also renewed the conversation on "globalization with Chinese characteristics" [Henderson, Appelbaum, Ho, 2013]. According to Jia Wenshan and Jiang Haofeng, the definition of "globalization 4.0" sustained by the fourth industrial revolution, is too narrowly focused on technology but should also take into account other dimensions of the structural crisis that accompanies the fourth global wave. For those two authors the term "globalization 4.0" as it was used at the 2019 Davos Forum is "another name for Industry 4.0, downplaying or even ignoring the fact that globalization should be an all-encompassing and grander narrative covering politics, economics, culture, science and technology" [Jia, Jiang, 2019]. Seen from this perspective, globalization with Chinese characteristics appears as a civilizational approach to the challenges of the fourth global wave, and has indeed been an important component of Beijing's narrative on the Belt and Road Initiative, also called the "New Silk Road." In practical terms, the civilizational approach has been implemented through a proactive promotion of connectedness or "connectivity politics" [Kohlenberg, Godehardt, 2018]. The gigantic set of projects encompassed by the BRI aims at connecting regions, countries and people with steel and concrete infrastructures, digital networks and more generally with tools that facilitate flows both domestically and internationally. Its focus on the "left-behinds" of globalization, first within China, in the Western and Central provinces, and then beyond it, in Central Asia and Africa, echoed with the global concern with growing inequalities.

Connectivity politics is therefore not only about connecting societies and communities but also about reconnecting entities that have been fragmented by the dynamics of rapid growth under the digital revolution, as the divide between those who have benefited from the global third industrial wave and those who were left behind, more than often crosses through countries - such as China or other emerging powers - that were on average less developed but somewhat more cohesive. In that sense the connectivity politics that inform the conception and implementation of the BRI is a response to the inclusiveness issues brought about by globalization 4.0. For Wang Huiyao, the ongoing multilateralization of the BRI, bringing in a growing 
number of stakeholders that makes it increasingly open and inclusive, gives this mega-project the potential to "work as a vector for globalization 4.0" [Wang, 2019].

The BRI is however still a work-in-progress; its development has not been without issues and has generated questions about transparency, accountability, and long-term viability, among others [Lindberg, Lahiri, 2018]. Yet it has also triggered emulation. The European Union and Japan have been drafting their own respective connectivity politics, and have as well signed in September 2019 the "EU-Japan Partnership on Sustainable Connectivity and Quality Infrastructure." This partnership, as its name indicates, aims at redefining the terms of connectivity politics by introducing a more normative content with sustainability and quality standards inspired by the UN's ambitious SDG program. This, in turn, has arguably had an impact on the official BRI's narrative. The concern for environmentally responsible and high-quality projects is now far more visible than it was in the early days of the OBOR. In his speech at the 2019 Belt and Road Forum, Chinese president Xi Jinping stressed that the Chinese initiative would "protect the common home we live" by building "high-quality, sustainable, risk-resistant, reasonably priced, and inclusive infrastructure" [Ministry of Foreign Affairs of the People's Republic of China, 2019].

\section{Empowerment}

Connectivity politics might, in the longer term, contribute to the shaping of the new international architecture that the WEF is advocating for, but it is not, however, a direct response to the institutional issues put forward by the Davos Forum community. For the time being, connectivity initiatives offer solutions to the efficiency issues of globalization 4.0, and more specifically to the need for better distribution of wealth and inclusiveness within the new dynamics of the fourth industrial revolution. The implementation of such initiatives can differ from country to country and has not produced a unified global set of norms and practices. Projects and partnerships formed under the label of connectivity often converge towards similar goals that, added to each other, constitute a loose common agenda, such as the protection of "our common home," as president Xi Jinping put it. But as a policy paper by S. Grimm and S. Weinlich of the German Development Institute stresses, a tacit or even explicit consensus on the definition of a global common good is only a preliminary condition for the establishment of a solid international cooperation system and does not either guarantee the stability of such a system: the future of the multilateral system that was conceived during the 20th century is therefore uncertain [Grimm, Weinlich, 2020].

The weakening of multilateralism tends to be associated with the rise of populism, an association that seems, again, to be perfectly illustrated by American isolationism and the election of Donald Trump. Yet as Pierre Rosanvallon notes, one should distinguish the theatrics through which populism expresses a mood of disillusionment - with some real policy consequences from what actually feeds it. What is called populism is also a diversity of manifestations revealing a widespread expectation of a renewed social contract involving a stronger, more empowered civil society [Rosanvallon, 2019]. Without a larger and systematic acknowledgment of this expectation, the reconnection of "left-behind" people and communities with global development might prove difficult. But to be efficient such an acknowledgement cannot be confined to a domestic periphery or be an addition of national assessments. It has to be global in order to encompass the scope of the unevenness of globalization 4.0, and the broad phenomena of disruption and fragmentation that go with it. Both the 2019 Osaka G20 summit and the Biarritz G7 summit have given central stage to the issue of global inequalities. At the Biarritz gathering French president Emmanuel Macron underlined the importance of a rules-based international 
cooperation system as a "powerful tool to fight inequalities" [G7, 2019]. From that perspective it is not the principle of the current cooperation system - the assemblage of multilateral tools that needs to be revisited but its purpose.

Addressing the challenges of globalization 4.0 is evidently a multidimensional ambition for which there is no predefined roadmap. The limits of the modes of cooperation inherited from the post-Second World War, even with its successive amendments, engender a combination of issues of efficiency, legitimacy and anomy that seem to have reached a tipping point. The post1945 international architecture came with a normative package - shaped by Western liberalism but also by some of the counterpoints brought about by the decolonization movement and the Global South perspective - a repertoire of international norms that is now partly unravelling. New international norms might need to be defined in order to reset the global institutional framework of cooperation. The connectivity politics of China, Japan and the European Union, and their convergence toward the idea of "sustainable connectivity," indicate that the response to the problem of fragmentation characterizing globalization 4.0 cannot be a strictly technical, "value-free," one: normative choices seem inevitable. Making those choices will most probably entail a global battle of ideas and influence but, as again the example of connectivity politics within the Asia-Europe space shows, this battle will not necessarily lead to more division and can actually produce some new normative basis for international cooperation.

\section{References}

Adlen E. (2018) Trump, China, and Steel Tariffs: The Day the WTO Died. Council of Foreign Relations Blog, 9 March. Available at: https://www.cfr.org/blog/trump-china-and-steel-tariffs-day-wto-died (accessed 17 April 2020).

Baldwin R. (2019) The Globotics Upheaval: Globalization, Robotics and the Future of Work. Oxford University Press.

Baldwin R., Martin P. (1999) Two Waves of Globalisation: Superficial Similarities, Fundamental Differences. NBER Working Paper No 6904, National Bureau of Economic Research. Available at: https://www.nber.org/ papers/w6904.pdf (accessed 17 April 2020).

Bello W. (2002) Deglobalization: Ideas for a New World Economy. Zed Books.

Durkheim E. (1893) De la Division du Travail Social. Presses Universitaires de France.

Economic Commission for Latin America and the Caribbean (ECLAC). (2011) Global Governance at the Beginning of the 21st Century: What is the Role of the United Nations? Address Given by the President of the United Nations General Assembly H.E. Mr. Joseph Deiss, Santiago, 8 August. Available at: https://www.cepal. org/prensa/noticias/comunicados/6/44196/Deiss_cepal-governance-1108.pdf (accessed 17 April 2020).

Grimm S., Weinlich S. (2020) Multilateralism Without Future - Or the Future of Multilateralism? German Development Institute Blog, 8 January. Available at: https://blogs.die-gdi.de/2020/01/08/multilateralism-without-future-or-the-future-of-multilateralism/ (accessed 19 April 2020).

Group of 7 (G7). (2019) Biarritz Chair's Summary on Fighting Inequalities. Biarritz, 23 August. Available at: https://www.consilium.europa.eu/media/40530/biarritz-chair-s-summary-on-fighting-inequalities.pdf (accessed 17 April 2020).

Henderson J., Appelbaum R., Ho S.Y. (2013) Globalization With Chinese Characteristics: Externalization, Dynamics and Transformations. Development and Change, vol. 44, no 6, pp. 1221-53. Available at: https://doi. org/10.1111/dech.12066.

Jia W., Jiang H. (2019) Globalization 4.0 Should Go Beyond Technology and Economy. Chinese Social Sciences Today, 22 August. Available at: http://www.csstoday.com/Item/7071.aspx (accessed 19 April 2020).

Hirschman A. (1970) Exit, Voice and Loyalty. Harvard University Press. 
Kohlenberg P., Godehardt N. (2018) China's Global Connectivity Politics. SWP Comment, no 17, Stiftung Wissenschaft und Politik. Available at: https://www.swp-berlin.org/fileadmin/contents/products/ comments/2018C17_khb_gdh.pdf (accessed 19 April 2020).

Kirton J.J. (2013) G20 Governance for a Globalized World. Routledge.

Lindberg K., Lahiri T. (2018) From Asia to Africa, China’s “Debt-Trap Diplomacy” Was Under Siege in 2018. Quartz, 28 December. Available at: https://qz.com/1497584/how-chinas-debt-trap-diplomacy-came-undersiege-in-2018/ (accessed 19 April 2020).

Ministry of Foreign Affairs of the People's Republic of China. (2019) Working Together to Deliver a Brighter Future for Belt and Road Cooperation. Keynote Speech by H.E. Xi Jinping President of the People's Republic of China at the Opening Ceremony of the Second Belt and Road Forum for International Cooperation. Beijing, 26 April. Available at: https://www.fmprc.gov.cn/mfa_eng/zxxx_662805/t1658424.shtml (accessed 17 April 2020).

President of the Russian Federation. (2009) Interview With Dimitri Medvedev by Kirill Kleimenov for Channel One Russia. 18 June. Available at: http://en.kremlin.ru/events/president/transcripts/4514 (accessed 17 April 2020) (in Russian).

Rosanvallon P. (2019) Le Siècle du Populisme. Paris: Seuil.

Schwab K. (2016) The Fourth Industrial Revolution. What It Means, How to Respond. World Economic Forum. Available at: https://www.weforum.org/agenda/2016/01/the-fourth-industrial-revolution-what-it-meansand-how-to-respond/ (accessed 19 April 2020).

World Economic Forum. (2019) Globalization 4.0: Shaping a New Global Architecture in the Age of the Fourth Industrial Revolution. A Call for Engagement. White Paper. Available at: http://www3.weforum.org/docs/ WEF_Globalization_4.0_Call_for_Engagement.pdf (accessed 19 April 2020).

Wang H. (2019) China and Globalization: 40 Years of Reform and Opening-Up and Globalization 4.0. Journal of Chinese Economic and Business Studies, vol. 17, no 3, pp. 215-20. Available at: https://doi.org/10.1080/1476 5284.2019.1667099. 